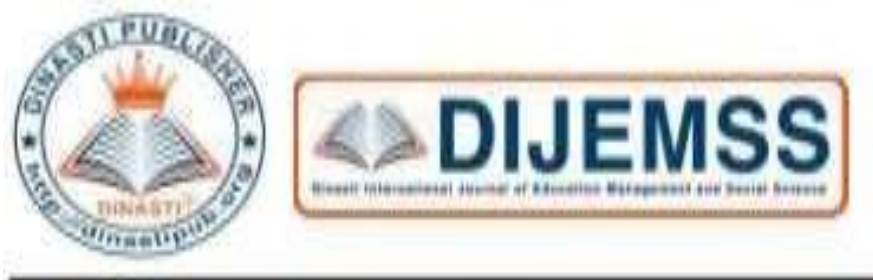

+6281387654578 (

081387654578 (1)

htps://dinatipuborg/DIJMSs (4)

editoradinastipub.ore 9

\title{
THE EFFECT OF WORKLOAD, WORK ENVIRONMENT, CARERR DEVELOPMENT ON EMPLOYEE JOB SATISFACTION ON PT. SARI COFFEE INDONESIA, Tbk.
}

\author{
Ryani Dhyan Parashakti ${ }^{1}$, Septiani Juniarti ${ }^{2}$, Nurul Khotimah ${ }^{3}$ \\ 1) Universitas Mercu Buana Jakarta, Indonesia \\ ${ }^{2)}$ Universitas Mercu Buana Jakarta, Indonesia \\ ${ }^{3)}$ Universitas Mercu Buana Jakarta, Indonesia
}

\begin{tabular}{|l|l|}
\hline ARTICLE INFORMATION & $\begin{array}{l}\text { Abstract: This research was conducted to determine } \\
\text { Received: 08/10/2019 } \\
\text { Revised: 13/10/2019 } \\
\text { Issued: 18/10/2019 } \\
\text { development on employee job satisfaction. The object } \\
\text { of this research is private employees of PT. Sari Coffee } \\
\text { Indonesia, Tbk (Case study of the Store Development } \\
\text { and Contarction division). This analysis uses } \\
\text { independent variables namely workload, work } \\
\text { environment and career development. This research } \\
\text { E-mail: } \\
\text { ryaniparasakti@gmail.com } \\
\text { was conducted on 50 respondents using quantitative } \\
\text { descriptive methods. Therefore, the data analysis used } \\
\text { is statistical analysis in the form of multiple linear } \\
\text { regression tests. The results of this study indicate that } \\
\text { workload and career development have a positive } \\
\text { effect on job satisfaction but partially and } \\
\text { simultaneously, the environment on job satisfaction of } \\
\text { employees of PT. Sari Coffee Indonesia, Tbk (Case } \\
\text { study of the Store Development and Contarction } \\
\text { division). This is evidenced from the partial results }(\mathrm{t} \\
\text { test) shows the significant value of the independent } \\
\text { variable, namely the work environment of 0,000 which } \\
\text { supports the hypothesis. In the test of Variance } \\
\text { Analysis (ANOVA) in the multiple regression equation } \\
\text { shows that the F-value is greater than the F-table (F }= \\
\text { 38.536> F-table }=2.41) \text { or the Probability Value is } \\
\text { smaller than 0.05. The value of the multiple correlation } \\
\text { coefficient (R) is 0.846 and R Square (R2) is 0.715. } \\
\text { The value of R Square (0.715) means that } 69.7 \% \text { of the } \\
\text { contribution of job satisfaction can be explained by the } \\
\text { three independent variables namely workload, work } \\
\text { environment and career development. Therefore the }\end{array}$ \\
\hline
\end{tabular}


results of this research test state that there is a positive influence between workload variables, work environment and career development on job satisfaction of employees of PT. Sari Coffee Indonesia, Tbk (Case study of the Store Development and Contarction division).

Keywords: Workload, Work Environment, Career Development, Job Satisfaction.

\section{INTRODUCTION}

\section{Research background}

Employees are a very important asset in every planning process and active actors in all company activities. They have different thoughts, feelings, desires and educational backgrounds that are brought into the company. Non-passive employees are material that can be controlled and fully regulated in supporting the achievement of company goals.

Quality Human Resources can be seen from the results of their performance while working, but not all employees can carry out their duties and obligations in accordance with their capabilities. Employees will feel comfortable if at work get job satisfaction in accordance with expectations (Koesmono, 2005).

In an organization to support the success of a company itself many factors that influence it. Employee satisfaction is one of the most important factors in helping to support the effectiveness of work and the achievement of targets set by each company. Job satisfaction is a psychological atmosphere about pleasant or unpleasant feelings towards their work (Davis, Keith, 1985). Meanwhile Porter and Lawler in Bavendam, J. (2000), explained that job satisfaction is a unidimensional building, where someone has general satisfaction or dissatisfaction with his work.

Job satisfaction is an important thing that individuals have at work. An employee who gets job satisfaction from his job, will maintain high work performance, and vice versa an employee who does not get satisfaction in his work, sooner or later will not be reliable, absent, and underperforming.

According to (Priansa, 2014) "Job satisfaction is a collection of employees' feelings towards their work, whether they like / dislike or dislike as a result of employee interactions with their work environment or as a result of employee evaluations of their work. The impact of employee job satisfaction on the company, namely:

1) Satisfied employees tend to work more productively

2) Satisfied employees tend to last longer in the company

3) Satisfied employees tend to create pleasant moods

4) Satisfied employees tend to have good work results.

Based on the phenomena and problems that occur at PT. Sari Coffee Indonesia, Tbk, researchers became interested in examining the level of employee satisfaction at this company and its relationship to things done by the company in increasing employee job satisfaction well in terms of workload problems, work environment and even how career development has an influence. 
Therefore, the researcher raised this research with the research title "Effect of Workload, Work Environment and Career Development on Employee Satisfaction of PT. Sari Coffee Indonesia, Tbk (STARBUCKS).

\section{Problem formulation}

1) Does the Workload affect the job satisfaction of employees of PT. Sari Coffee Indonesia?

2) Does the Work Environment on PT. Sari Coffee Indonesia?

3) Does Career Development affect the job satisfaction of PT. Sari Coffee Indonesia?

\section{Reserach purposes}

a. to find out the influence of workload variables in supporting job satisfaction for PT. Sari Coffee Indonesia.

b. to determine the effect of work environment variables on job satisfaction of PT. Sari Coffee Indonesia.

c. to determine the effect of the variable career development program (training program) held on job satisfaction (job satisfaction) employees of PT. Sari Coffee Indonesia

\section{LITERATURE REVIEW}

\section{Workload}

According to Danang Sunyoto (2012), workload is too much to cause tension in a person, causing stress. This can be caused by the level of expertise required is too high, the speed of work may be too high, the volume of work may be too much and so on.

According to Adil Kurnia (2010), workload analysis is identifying both the number of employees and the qualifications of employees needed to achieve organizational goals. According to Adil Kurnia (2010), the definition of workload is a group or a number of activities that must be completed by an organizational unit or position holder within a certain period of time.

\section{Work environment}

The work environment is the social, psychological, and physical life in a company that influences workers in carrying out their duties. Human life is inseparable from the various circumstances surrounding the environment, between humans and the environment there is a very close relationship.

In every organization has and is influenced by the environment, one environment in the organization is the work environment. As we already know that the work environment is a social, psychological, and physical life in an organization that influences workers in carrying out their duties, work and obligations. The employees in carrying out their work are inseparable from various conditions in the surrounding environment, between workers and the environment there is a very close relationship. In this case, workers will always try to adapt to various conditions of the surrounding environment. Employees cannot be separated from various conditions around where they work, namely the work environment. During 
work, each employee will interact with various conditions contained in the work environment.

\section{Employee Satisfaction}

Job Satisfaction According to Edy Sutrisno (2014) job satisfaction is a quite interesting and important problem, because it has proven to be of great benefit to the interests of individuals, industry and society. For individuals, research on the causes and sources of job satisfaction enables efforts to increase their happiness in life. For industry, research on job satisfaction is carried out in an effort to increase production and influence costs through improving the attitudes and behavior of its employees.

Job satisfaction reflects someone's feelings towards their work. According to Siagian (2013) job satisfaction is a person's perspective both positive and negative about his job 20 Many factors that affect employee satisfaction. The factors themselves in their role of providing satisfaction to employees depend on each individual employee.

\section{Relationship Between Variables \\ Relationship between Workload and Employee Satisfaction}

Hart and Staveland (in Wikipedia, 2008) defines workload as follows: "the perceived relationship between the amount of mental processing capability or resources and the amount required by the task". From some understanding of workload, it can be concluded that workload is "a number of activities that require mental processes or abilities that must be completed within a certain period of time, both in physical and psychological form.

Stress is an internal condition that occurs with marked physical, environmental, and social situations that have the potential to lead to adverse conditions. Opinion was expressed by Morgan \& King, (1986) which is more clear as follows: "... an internal state which can be caused by physical demands on the body (disease conditions, exercise, extremes of temperature, and the like) or by environmental and social situations which are evaluated as potentially harmful, uncontrollable, or exceeding our resources for coping "

\section{Relationship of Work Environment with Employee Satisfaction}

According to Greenberg and Baron (1993) there are conditions in the organizational environment or work environment that affect the level of employee job satisfaction:

a) Elements of work Elements such as challenges in work and variations in work affect employee job satisfaction. Because these elements will attract employees and naturally will make employees more involved with their work. It's just that the level of challenge and variation must be at a moderate level, because the level is too high, it causes frustration.

b) Payroll system 5 Payroll system affects employee job satisfaction because it is a reward received by employees for the effort and productivity that has been done, but it also acts as a means of satisfying needs, needs, physical, status symbols, and creating a sense of security. Thus the payroll system that is perceived as fair and strong will lead to job satisfaction.

c) Promotion Opportunity to be promoted will lead to job satisfaction because it relates to salary increases, recognition, feelings of respect and status symbols. 
d) Verbal recognition Locke (1976) says that recognition can lead to job satisfaction, especially for lower-level employees, because the need to feel valued will be fulfilled as well as self-esteem needs, and self-concept.

e) Conditions of the work environment Enjoyable working environment conditions will lead to job satisfaction, because good environmental conditions will support the completion of work. Work environments that are too extreme such as: air temperature, lighting, ventilation, and noise will affect job satisfaction because it can lead to physical disturbances.

f) Decentralization of power Decentralization in question is the division of authority and power, by not giving to just one person. This will lead to satisfaction because employees can participate in decision making, and the need for a sense of self-competence, autonomy, and power will be met.

g) Supervision, coworkers and subordinates Supervision in question is the perception of employees of the quality of superiors (supervision) which includes, style of supervision, supervision techniques, interpersonal relationship skills, and administrative skills. Whereas coworkers and subordinates deal with issues of competence, willingness to help, and friendship.

h) Company policy The policy in question is related to administrative issues, work procedures, regulations, policies and actions taken by the company for the benefit of the company.

\section{Relationship between Career Development and Job Satisfaction}

According to Rivai and Sagala (2009) aspects contained in individual career development are:

a) Job performance is the most important component for career development, the most important for improving and developing an employee's career. Career progress is largely dependent on good and ethical work performance. By knowing the results of their performance, employees can measure their opportunities for career development.

Assumptions for good performance will underlie all career development activities. When performance is below the standard, by ignoring efforts towards career development, even the simplest career goals cannot be achieved. Career progress generally lies in performance and achievement.

b) Recognition by other parties (Exposure) Without recognition by other parties, good employees will not get the opportunities needed to achieve their goals. The manager or supervisor gets this introduction mainly through employee performance and achievements, written reports, oral presentations, committee work and hours spent.

\section{Hypothesis}

H1: Workload affects employee satisfaction

H2: Work Environment influences Employee Satisfaction

H3: Career development influences employee satisfaction. 


\section{RESEARCH METHODS}

1) Questionnaire Techniques

According to Sugiyono (2013), the questionnaire is a data collection technique that is done by giving a set of written questions to respondents to answer.

2) Observation Method

According to Sutrisno Hadi, quoted by Sugiyono (2013) observation is a complex process, a process that is composed of various biological and psychological processes. By using the method of observation, the authors do addressing by plunging into the field to the object under study, then note the importance of the research object.

\section{Result and Discussion}

\section{Normality test}

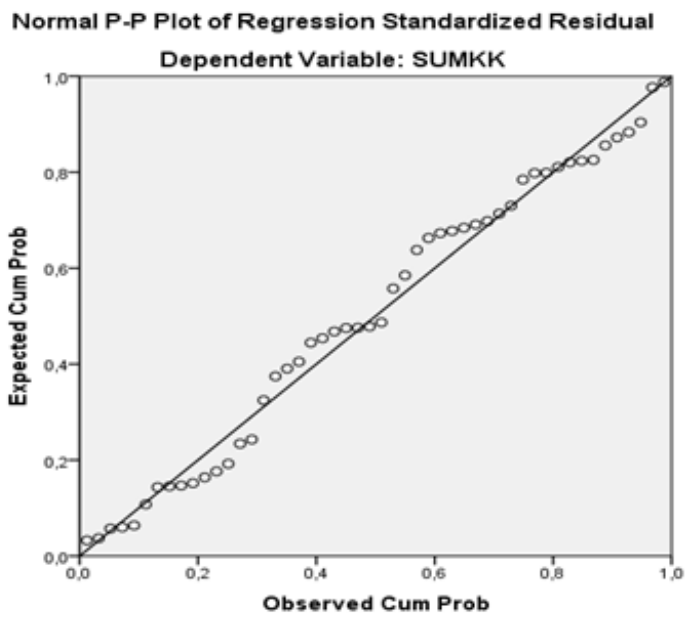

Figure 1. Normality test Result

The basis for decision making is as follows:

a. If the data spreads around the diagonal line and follows the direction of the diagonal line, the regression model meets the normality assumption.

b. If the data spreads far from the diagonal line and or does not follow the direction of the diagonal line, the regression model does not meet the assumption of normality.

From Figure 4.1 it can be seen that the points that spread and around the diagonal line and spread also follow the direction of the diagonal line. This proves that the regression model has fulfilled the normality assumption.

\section{Multikolinierity test}

Table 1. Multikolinierity test Result

\begin{tabular}{lll}
\hline \multicolumn{2}{c}{ Coefficients $^{\mathbf{a}}$} & \\
\hline Model & \multicolumn{2}{l}{ Collinearity Statistics } \\
\cline { 2 - 3 } & Tolerance & VIF \\
\hline Beban Kerja & .478 & 2.093 \\
\hline Lingkungan Kerja & .385 & 2.596 \\
\hline Pengembangan Karir & .452 & 2.212 \\
\hline
\end{tabular}




\section{Multiple Linear Regression Test Results}

And from the data processing results obtained regression coefficients from the table above as follows:

$\mathrm{Y}=\mathrm{a}+\mathrm{b} 1 \mathrm{X} 1+\mathrm{b} 2 \mathrm{X} 2+\mathrm{b} 3 \mathrm{X} 3+\mathrm{e}$

$Y=-2,085+0,221 X_{1}+0,719 X_{2}+0,090 X_{3}+e$

From the mathematical equation, the multiple linear regression can be concluded as follows:

a. The constant of $-2,085$ is the intersection of the regression line with the $\mathrm{Y}$ axis which shows job satisfaction when the organizational variable store development and contraction division when the independent variable, namely workload (X1), work environment (X2) and career development (X3) equals zero (0).

b. Workload variable (X1) has a positive regression coefficient, meaning that if the workload variable (X1) increases by one unit, the work satisfaction of the store development and contraction division organizations will increase by the regression coefficient value 0.221 assuming the other independent variables are fixed.

c. The work environment variable (X2) has a positive regression coefficient, meaning that if the work environment variable (X2) increases by one unit, the job satisfaction of the organization's store development and contraction division will increase by the regression coefficient value of 0.719 assuming the other independent variables remain constant.

d. Career development variable (X3) has a positive regression coefficient, but a decrease in the coefficient value means that if the career development variable (X3) decreases by one unit, the job satisfaction of the organization's store development and contraction division will decrease by the regression coefficient value of 0.090 assuming Other independent variables remain.

\section{Hypothesis Test Results}

Determination Coefficient Test $\left(\mathbf{R}^{2}\right)$

Table 3. Determination Coefficient Test Result Model Summary ${ }^{b}$

\begin{tabular}{ccccc}
\hline Model & $\mathrm{R}$ & $\mathrm{R}$ Square & Adjusted R Square & Std. Error of the Estimate \\
\hline 1 &, $846^{\mathrm{a}}$ &, 715 &, 697 & 5,545 \\
\hline
\end{tabular}

a. Predictors: (Constant), Pengembangan

Karir, Beban Kerja, Lingkungan Kerja,

b. Dependent Variable: Kepuasan Kerja

Source: SPSS 20 (2018)

Based on the table, it is known that the coefficient of determination (adjusted $\mathrm{R}^{2}$ ) is 0.697, which means $69.7 \%$, which means that the contribution of job satisfaction can be explained by the three independent variables, namely workload, work environment and career 
development. So the rest of $30.3 \%(100 \%-69,7 \%)$ is explained by other variables not examined in this study.

\section{Test of Significance (t Test)}

The $t$ test statistic basically shows how far the influence of one explanatory or independent variable individually in explaining the variation of the dependent variable. Decision making can be done by looking at the probability. If probability / significance> 0.05 then $\mathrm{Ho}$ is accepted and $\mathrm{Ha}$ is rejected and if probability / significance $<0.05$ then Ho is rejected and $\mathrm{Ha}$ is accepted.

Testing this hypothesis to find out whether the independent variable influences the dependent variable and which independent variable is the most dominant influence on Employee Productivity.

From the results of the $t$ test showed that there are 2 independent variables have an influence but not significant to the dependent variable and 1 independent variable has a significant effect on the dependent variable.

The details can be explained as follows:

Hypothesis Testing Workload on Employee Satisfaction

Based on the probability of sig workload of 0.119 greater than 0.05 so that Ho is accepted and $\mathrm{Ha}$ is rejected, it can be stated partially Workload (X1) does not significantly influence job satisfaction $(\mathrm{Y})$.

Hypothesis Testing the Work Environment on Employee Satisfaction

Based on the work environment sig probability table of 0,000 less than 0.05 , so that Ho is rejected and $\mathrm{Ha}$ is accepted, it can be stated partially the work environment (X2) has a significant effect on job satisfaction (Y).

Hypothesis Test The Effect of Career Development on Employee Satisfaction

Based on the probability table of work discipline sig for 0,400 greater than 0.05 , so that Ho is accepted and $\mathrm{Ha}$ is rejected, it can be stated partially that work discipline (X3) has no significant effect on job satisfaction (Y).

\section{FINDINGS AND DISCUSSION}

\section{Effect of Workload on Job Satisfaction}

Based on the results of the $t$ test calculations show the results of the $t$ value of 1.588 and a significance value of 1.14 greater than 0.05 . So it can be concluded that the workload variable has a positive but not significant effect on job satisfaction at PT. Sari Coffee Indonesia, tbk store development and contraction division. The higher workload, the meaning will affect the work satisfaction of the employees themselves. From the results of the study due to the acceptance of workloads that are not the responsibility of that part of the work itself, but subordinates or employees continue to work well to meet the needs of daily life. This possibility can be related to Maslow's hierarchy of needs theory about psychology. The results of this study are also consistent with Mustapha and Ghee's (2013) research which states that 74 workloads affect employee job satisfaction. Employees who have high workloads will reduce their job satisfaction. 


\section{Effect of Work Environment on Job Satisfaction}

Based on the results of the $t$ test calculations show the results of the $t$ value of 4.992 and a significance value of 0.000 less than 0.05 . So it can be concluded that the work environment variables have a positive and significant effect on job satisfaction at PT. Sari Coffee Indonesia, tbk store development division. This shows the factors such as employee relations, lighting, work regulations, air circulation, noise and safety that form a work environment that is very influential in increasing and influencing job satisfaction at PT. Sari Coffee Indonesia, tbk store development and contraction division

\section{Effect of Career Development on Job Satisfaction}

Based on the results of the $t$ test calculations show the results of the $t$ value of 0.850 and a significance value of 0.400 greater than 0.05 . So it can be concluded that the career development variable has a positive but not significant effect on job satisfaction at PT. Sari Coffee Indonesia, tbk store development and contraction division. This result is not in line with the results of research conducted by Kaswan (2014) "career development is the result of integration between individual career planning and organizational career management processes". Career development is very important for both individuals and organizations. Career development practices are proven to increase employee career satisfaction and increase organizational effectiveness.

\section{CONCLUSION AND SUGESTION}

\section{Conclusion}

Based on the results of research and discussion in the previous chapter about the effect of workload, work environment and career development on job satisfaction at PT. Sari Coffee Indonesia, tbk store development division as follows:

1) Workload has a positive but not significant effect on job satisfaction. With the current workload, there is no need for significant changes or re-planning so that PT. Sari Coffee Indonesia, tbk store development and contraction division.

2) The work environment has a positive and significant effect on employee job satisfaction. This means that with the current working environment, it is necessary to improve and improve the physical and non-physical work environment in order to increase job satisfaction for the employees of PT. Sari Coffee Indonesia, tbk store development and contraction division.

3) Career Development has a positive and not significant effect on employee job satisfaction. This means that career development that already exists in PT. Sari Coffee Indonesia, tbk has gone well according to the KPI determined by each division, thereby increasing employee job satisfaction itself.

\section{Suggestion}

Based on the conclusion above, suggestions can be given as follows:

\section{Suggestions For Companies}

It is expected that companies pay more attention to the work environment, especially those found at several points, namely: 
a. The availability of facilities to support this work can be seen from the results of table 4.7 point 6 , where the company is expected to provide better facilities so that employees can complete their duties and responsibilities properly.

b. Air ventilation within the scope of work at this time still requires special attention from the company in supporting activities that are in the scope of work, and to create a comfortable work space for all employees, this can be seen from the results of table 4.7 point 2.

c. Can be seen from the results of table 4.7 point 11 , where the role of superiors as internal system support is not going well. For this reason, it is expected that there will be support or encouragement from superiors in improving employee performance so that they are motivated to want more.

d. Besides coworkers in the same scope of lack of attention to each other in completing work together, which should be communicated properly in order to create a good relationship between every employee in PT. Sari Coffee Indonesia, especially in the store development and contraction division.

\section{For Further Research}

In connection, this study has limitations in conducting research, it is recommended for further researchers who want to examine related variables contained in this study, namely Workload, Work Environment and Career Development on Employee Satisfaction. So that further research can develop other variables such as compensation, satisfaction, work stress and workload so that it can be used as a reference to examine variables that have never been done or use other research objects and by adding the number of respondents in different research objects.

\section{REFERENCES}

Anak Agung Ngurah Bagus Dhermawan ,I Gde Adnyana Sudibya, I Wayan Mudiartha Utama. Jurnal Manajemen, Strategi Bisnis, dan Kewirausahaan Vol. 6, No. 2 Agustus 2011

Davis, Keith dan John W. Newstrom. 1985. Perilaku Dalam Organisasi. Jakarta : Erlangga.

Dhini Rama Dhania Universitas Muria Kudus, Prngaruh Stress Kerja, beban Kerja Terhadap kepuasan Kerja (Studi Pada Nedical representatif di Kota Kudus). Volume I, No 1, Desember 2011

e-jurnal.com/2013/09/variabel-variabel-kepuasan-kerja

Edisi Agustus 2016 ISSN : 2540-816X JURNAL Ecoment Global 75

Feru Liawandy Sri Indarti Marzolina. Jom FEKON Vol. 1 No. 2 Oktober 2014

Gunawan. 2015. Pengaruh Lingkungan Kerja Terhadap Kepuasan Kerja Karyawan Bagian

Kantor pada PT. Maton Land Pekanbaru. Skripsi tidak diterbitkan. Pekanbaru: Fakultas Ekonomi UIN Sultan Syarif Kasim Riau.

Hadinata, Himawan. 2014. Pengaruh Lingkungan Kerja dan Kompensasi tehadap Kepuasan Kerja Karyawan Pabrik Genteng Massokka Kebumen, Jawa Tengah.

Hasibuan, Malayu S.P. 2007. Manajemen Sumber Daya Manusia. Bandung: PT Bumi Aksara Hasibuan, Malayu S.P. 2012. Manajemen Sumber Daya Manusia. Edisi Keenam belas. Jakarta: PT Bumi Aksara. Hendri, Edduar. 2012. 
Hendri, Edduar. 2012. Pengaruh Lingkungan Kerja Fisik dan Non Fisik terhadap Kepusan Kerja Karyawan PT. Asuranasi Wahana Tata Cabang Palembang. Jurnal Media Wahana Ekonomika, (Online), Vol. 9, No.3, (http://www.univpgri-palembang.ac.id, diakses pada 3 November 2015).Adil Kurnia, 2010. Workshop Workload Analysis Beban Kerja : Surabaya

I Gusti Gede Djestawan. Pengaruh Pengembangan Organisasi, Kepemimpinan, Jenjang Karir terhadap Kepuasan Kerja dan Kinerja Pegawai Puskesmas. National Public Health Journal Vol. 6 No. 6 Juni 2012

I Gede Mahendrawan, Ayu Desi Indrawati. Pengaruh Beban Kerja dan Kompensasi Terhadap Kepuasan Kerja PT. Panca Dewata Depasar. E-Jurnal Manajemen Unud, Vol. 4, No. 11, 2015: 3936-3961 ISSN : 2302-8912 - 3936 Jurnal Arika, Vol. 05. No. 2 (Agustus 2011). ISSN: 1978-1105. Volume 1 No.2

Koesmono, T. 2005, Pengaruh Budaya Organisasi Terhadap Motivasi dan Kepuasan Kerja Serta Kinerja Karyawan Pada Sub Sektor Industri Pengolahan Kayu Skala Menengah Di Jawa Timur, Jurnal Manajemen dan Wirausaha Vol. 7. No. 2 September 2005.

Veithzal Rivai dan Ella Jauvani Sagala, 2011. Manajemen Sumber Daya Manusia untuk Peursahaan dari Teori ke Praktik. PT Raja Grafindo, Jakarta

Mamik Eko Supatmi, Umar Nimran, Hamidah Nayati Utami. Pengaruh Pelatihan, Kompensasi terhadap kepuasan kerja karyawan dan kinerja karyawan. Jurnal Profit Volume 7 No. 1

Mangkunegara,A.P, (2013). Manajemen sumber daya perusahaan , Cetakan Kesebelas, Bandung : PT Remaja Rosdakarya Offset.

Ramlan Ruvendi : Imbalan dan Gaya Kepemimpinan Pengaruhnya Terhadap Kepuasan Kerja Karyawan, Balai Besar Industri Hasil Pertanian Bogor.

Sugiyono.2013. Metode Penelitian Pendidikan Pendekatan Kuantitatif, Kualitatif, dan R\&D. Bandung: Alfabeta 